http://jmscr.igmpublication.org/home/ ISSN (e)-2347-176x ISSN (p) 2455-0450

crossref DOI: https://dx.doi.org/10.18535/jmscr/v8i10.33

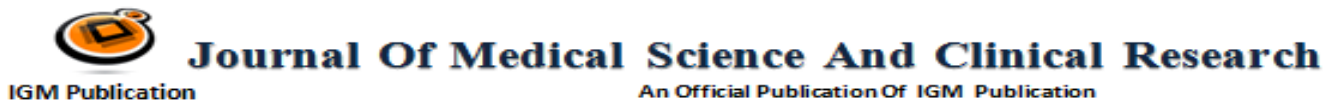

\title{
Short Term Functional outcome of Ponseti's Method in Infants with Congenital Talipes Equinovarus
}

Authors

\section{Dr Sudhir Ravindran, Dr Arunraj M V}

\section{Introduction}

Clubfoot or congenital talipes equinovarus is a congenital birth abnormality affecting feet which causes cosmetic abnormality and progressive difficulty in walking. In most cases etiology is unknown even though there are many theories regarding the same. It is said to be seen in 1 out of 1000 live births.

It is managed now with Ponseti technique developed by Ignacio V. Ponseti in the 1940s. One of the major principles of this technique is the concept that the tissues of a new-born's foot, including tendons, ligaments, joint capsules, and certain bones, will yield to gentle manipulation and casting of the feet at weekly intervals. This has brought a drastic change in the treatment and hence has improved the results of clubfoot treatment without resorting to major surgeries.

This treatment is economical and when implemented correctly, will significantly result in deformity correction in children with clubfoot. Major manipulation and surgical procedures are avoided. The feet gets improved in appearance and function. Also the long term complications of uncorrected feet like osteoarthritis and painful bursitis don't happen with this treatment.

\begin{abstract}
Aim of the Study
The aim of our study is to explore the functional outcome of Ponseti method for the management of congenital talipes equinovarus in children less than 12 months who attended at club foot clinic of orthopaedic outpatient department, medical college Thiruvananthapuram.
\end{abstract}

\section{Primary Objective}

The objective of the study is to evaluate the functional outcome of Ponseti method for the management of congenital talipes equino varus in patients less than 12 months, who attended the clubfoot clinic of orthopaedic outpatient department of medical college Thiruvananthapuram using Catteral/Pirani scoring system and Dimeglio/Bensahel scoring system.

\section{Secondary Objective}

The socio-demographic information of the study patients are also tabulated and evaluated.

\section{Review of Literature}

Congenital talipes equinovarus or clubfoot is one of the most common birth defects involving the musculoskeletal system. Idiopathic clubfoot is an isolated deformity of the foot and leg that is identifiable in utero and consists of four 
components: equines, hind foot varus, forefoot adductus, and cavus.

\section{Etiology}

Clubfoot deformity may be idiopathic (no known cause) or associated with myelodysplasia, arthrogryposis, poliomyelitis sequalae or even part of other congenital abnormalities. The most common presentation is an isolated birth defect and so considered idiopathic. The secondary clubfeet (clubfoot due to other known causes behave in a different way than the idiopathic ones and are usually resistant to treatment.

Using a candidate gene approach, common genetic variants have been associated with clubfoot including variants in homeodomain transcription factors HOXD12 and HOXD13, and several apoptotic genes including the caspase genes.

The identification of the exact aetiology of clubfoot may eventually be helpful in determining both prognosis and the selection of appropriate treatment methods in an individual patient.

\section{Treatment of Clubfoot}

Kite in 1939 introduced a method of manipulation that primarily involved serial manipulations and casting. Correction of the heel varus was attempted by abducting the foot at the midtarsal joints and by applying direct pressure on the calcaneocuboid joint. However, by abducting the forefoot in this manner, the calcaneus was actually blocked from adducting under the talus and the heel varus persisted. Therefore, because of this fundamental flaw in technique, this method of correction was often quite lengthy with children being casted for up to 2 years. In addition, $50 \%$ to $75 \%$ of patients still required soft tissue release surgery because of incomplete corrections. Also patients finally ended up with stiff painful feet due to the scaring of the surgeries.

\section{Ponseti Method}

The Ponseti method is a method of serial manipulation, casting, and tenotomy of the Achilles tendon to achieve correction of the clubfoot. This method included weekly serial manipulation of all deformities except equinus followed by abduction bracing to retain correction as well as strategies to treat relapses once they occur based on age of the child. The parents are clearly explained about the procedure along with the duration, the need for regular visits, plaster and tenotomy care protocols and use of brace. Even though there are a few dropouts (due to various personal reasons) most of them comply and achieve excellent results due to its child friendly approach as against older painful manipulation techniques.

The treatment is ideally started as early as possible within the first few weeks of life and consists of gentle manipulation of the foot in an office setting followed by serial application of a long leg cast as described by Ponseti. Though Ponseti advocates the use of plaster for the cast material as it is easier to mould, the fiberglass materials can also be used for achieving clubfoot correction. Regardless of the casting material used, the casts are changed every 5 to 7 days.

Children over 3 year of age present with hindfoot varus in combination with a dynamic supination of the forefoot observed while walking require a different approach. The varus of the heel and adduction of the foot are first corrected with serial casting. Once these deformities are corrected a full tibialis anterior tendon transfer to the third cuneiform is performed. The child is casted for6 weeks postoperatively, but there is no need for use of the foot abduction brace after this procedure. The physical therapy can be incorporated into the post casting regime for these patients to help with gait training and muscle strengthening.

\section{French Method}

Another popular method of clubfoot treatment that also avoids extensive surgical treatment is the French or functional method. This method requires daily manipulations of the new-born clubfoot by a skilled physiotherapist followed by immobilization with adhesive taping to maintain the correction achieved with stretching. 


\section{Role of Surgery in Clubfoot Correction}

The use of surgery for primary clubfoot correction today has been limited to an "a la carte" approach, where structures are released only as and when needed to obtain correction as an adjunct to a more conservative manipulative approach. The vast majority of idiopathic clubfeet should be treated with casting and a percutaneous Achilles tendon Tenotomyalone.

\section{Club Foot Scoring Systems}

There is no agreed method of grading the severity of deformity or monitoring the natural history, but there is a reported need for such a classification .which should be reliable, reproducible, feasible in a clinical setting, and predict appropriate treatment.

Pirani et aldevised a simple scoring system based on six clinical signs of contracture. Each is scored according to the following principle: 0 , no abnormality; 0.5 , moderate abnormality; 1 , severe abnormality. The six signs are separated into three related to the hindfoot (severity of the posterior crease, emptiness of the heel and rigidity of the equinus), and three related to the midfoot (curvature of the lateral border of the foot, severity of the medial crease and position of the lateral part of the head of the talus). Thus, each foot can receive a hindfoot score between 0 and 3, a midfoot score between $\mathrm{O}$ and 3 and a total score between 0 and 6 . Score are interpretation when assessed for inter-observer reliability, the kappa score showed this to be almost perfect and much better than any of previous scoring system

Dimeglio and his colleagues divided clubfoot deformity into four measurable anatomical features, or subgroups, which are scored on a scale of 20 points. These subgroups are equinus in the sagittal plane, varus deviation in the frontal plane, derotation around the talus of the calcaneus causing-forefoot block, and adduction of the forefoot on the hindfoot in the horizontal plane. Each subgroup is assessed in severity from 1 to 4 points. In the presence of a posterior or medial fold, extreme cavus and/or muscle weakness, another point is added to each category for a possible total of 5 points.

The Dimeglio and Pirani scoring systems are useful in evaluating the degree of correction of the foot as well as the potential for the prognosis of the disease.

The superiority of any one scoring system over another has not been validated yet.

\section{Materials and Methods}

Study Design: Hospital level prospective, descriptive study.

Study Setting: Clubfoot clinic in Orthopaedic Out Patient Department, Govt. Medical College Hospital Thiruvananthapuram, a tertiary care referral and teaching hospital.

Study Period - 1 year (Jan 2015 to Dec 2015)

Study Population- Infants having Idiopathic Congenital Talipes Equinovarus, both unilateral and bilateral foot.

Inclusion Criteria- Patients both male and female with club foot for whom casting method was employed by Ponseti technique for at least three consecutive treatment session.

\section{Exclusion Criteria}

1. Children with clubfeet above the age of 12 months. 2 Children with teratologic clubfoot. 3 Children with syndromic associations. 4 Recurrent and relapsed clubfeet consequent to failed surgical treatment. 5 Patients who discontinued their treatment from Outpatient Unit. 6 Patients who did not receive casting for minimum three sessions in outpatient unit.

Sample Size- All patients satisfying the inclusion criteria of congenital talipes equino varus who were attended the clubfoot clinic in the first six months of the study and followed up for a period of three to six months. And so the sample size is 40.

Data Collection Tool- clinical examination, clinical records. Patients are assessed by semistructured questionnaire, Catteral/ Pirani scoring system and Dimeglio/ Bensahel scoring system.

Informed Consent- Informed consent was obtained from the parents of the patient after 
counselling them regarding the benefits of the treatment and their active role in the treatment protocol as emphasized by Ponseti himself.

Study Procedure- The socio-demographic details of the patients were assessed in the first sitting itself using the questionnaire and the clubfeet are initially assessed with Pirani scoring system and Dimeglio/Bensahel scoring system. After counselling the parents, and with their full active involvement to direct away the child's attention, and with the help of an assistant, the clubfeet were manipulated strictly in accordance to the scheme described by Ponseti.

First Cast: Prior to casting, the position of the forefoot in relation to the heel is assessed for any abnormally high arch (cavus) of the foot. The first cast application addresses this foot deformity, aligning the forefoot with the hindfoot. By doing this, the cavus is corrected typically after one cast. First a short-leg cast was applied to just below the knee, which was then extended above the knee. Ponseti emphasizes the importance of long-leg casts, which are essential to maintain adequate stretching of tendons and ligaments.

Second Cast: After one week the first cast is removed and after a short period of manipulation the next long leg (toe to groin) plaster cast is applied. This manipulation and casting is focused on straightening the foot, aligning the forefoot with the heel. Further Casting: Manipulation and casting was continued on a weekly basis for the next two to six weeks in order to gradually straighten the forefoot, allowing the forefoot to move in line with the heel.

Every foot was scored each week for HS, MS, and total score. Pirani score was the road to treatment. Tendoachilles Tenotomy is indicated when HS $>1$, MS $<1$, and the head of talus is covered, that is score ' 0 '. The Dimeglio score was also assessed at each visit. The Achilles tendon percutaneous release is a quick procedure that is typically done through a small puncture, under local anesthesia.

The final cast: After the tenotomy the foot and ankle are then casted in the final corrected position with Achilles tendon stretched further and the forefeet pointed upward. After removal of the final cast, the infant is placed into a brace, which maintains the foot in its corrected position. Brace was prescribed by usual bracing protocol as described by Ponseti; and was applied immediately after the last cast was removed, 3 weeks after tenotomy. The brace should be worn full time (day and night) for the first 3 months after the last cast was removed. After that, the child should wear the brace for 12 hours at night and 2 to 4 hours in the middle of the day for a total of 14 to 16 hours during each 24 hour period. Children were assessed after the end of casting treatment, at 3 months in the bracing period and at 6 months of follow up using Catteral/Pirani scoring system and Dimeglio/Bensahel scoring system. The treatment was considered as success if pirani score was $<=0.5$ at the end of treatment.

Data Management and Analysis- Data was entered into Microsoft excel sheet and appropriate statistical test were applied based on the variables using SPSS software.

Ethical Issue- Approval obtained from the Superintendent Govt. Medical College Thiruvananthapuram, The Head of the Department of Orthopaedics, Govt. Medical College Thiruvananthapuram .a research committee and the institutional ethical committee of Medical College Thiruvananthapuram. The investigator strictly followed the guidelines given by local ethical review committee according to rules and guidelines of WHO and local research committee. The questionnaire was developed and approved by supervisor of the researcher. All the data was reviewed in strict secure and maintained.

\section{Results and Analysis}

Quantitative variables are presented as mean \pm SD or median (range).

In the group, comparison of qualitative variables were analysed with Wilcoxon rank test, chi-square test with Friedman test where ever necessary.

Between Qualitative variables are described by frequency distribution. 
Groups, comparison of qualitative variables were analysed by chi-square test with Fischer's Exact test. Correlation is assessed by spearman's rho test.

Between groups, comparison of quantitative variables were analysed by t-test

A p-value of 0.05 was taken as the level of significance.

Data were statistically analyzed with the use of the Statistical Package for Social

Science Program (SPSS version 22.0.0 for Windows)

A total of 40 patients contributing a total 59 foot were studied. $26(65 \%)$ were males and 14(35\%) were females.

\begin{tabular}{|l|c|c|}
\hline SEX & Number of patients & Percentage \\
\hline Male & 26 & 65 \\
\hline Female & 14 & 35 \\
\hline Total & 40 & 100 \\
\hline
\end{tabular}

Mean age in weeks at the start of the treatment was 7.15(SE-1.08) (Range 1-30 weeks) with median age of 4 weeks. 14 patients were only 1 week of age, four patients each were 4 weeks and 2 weeks of age. Three patients each were 9 and 7 weeks of age. Two were 10 weeks old. One patients each with $3,5,6,8,18,21,25,26,28$, and 30 weeks of age. From this it is clear that most of the patients are younger than two months of age.

\begin{tabular}{|l|c|c|c|}
\hline Involvement & Female & Male & Total \\
\hline Unilateral & 9 & 12 & 21 \\
\hline Bilateral & 5 & 14 & 19 \\
\hline Total & 14 & 26 & 40 \\
\hline
\end{tabular}

$23(57.5 \%)$ were first born, 14(35\%) were second born and 2(5\%) third born. Only one patient $(2.5 \%)$ was first child of the twins and the second child was normal. 19 patients $(47.5 \%)$ were bilaterally affected and 21(52.5\%) has unilateral disease.

Only 4(10\%) are from urban area and rest $36(90 \%)$ are from rural area

16 patients $(40 \%)$ are from nuclear family and $24(60 \%)$ patients are from extended type of family.
$6(10 \%)$ patients are preterm babies and rest of them are full term delivery with no post term babies.

23(57.5\%) were first born, 14(35\%) were second born and 2(5\%) third born. Only one patient $(2.5 \%)$ was first child of the twins and the second child was normal.

Only $2(5 \%)$ child has family history of clubfoot. None of the patients had other comorbidities also none of them has post natal complications

Only 2(5\%) child has family history of clubfoot.

None of the patients had other comorbidities also none of them has post natal complications.

Dimeglio score at initial presentation was Type III for 48 feet (81.4\%) and Type IIb for rest of the 11 feet. At the completion of casting treatment all of them are Type I, and at 6 months 57 feet $(96.6 \%)$ had typel score and 2 feet $(3.4 \%)$ had Type Ha score.

Median intial pirani score was (range 3 to 6) after the casting the median score was 0.5 (range 0-1) and the dimeglio score at the same time was 19 (range 14-19) and 4 (range 4-5) respectively.

Out of the 23 tenotomy feet, 10 foot was of female children and 13 were of male. Of the nontenotomy group 9 foot was of female and 27 of male children. Also there was no complication related to tenotomy neither on performing nor on follow up.

There was no statistically significant difference in the incidence of tenotomy in female and male children as determined by Fisher's Exact test (chi square value $2.195, \mathrm{P}=0.138$ ). Out of 23 tenotomy foot 12 were left and 11 right and in nontenotomypatients, out of 36, 18 each were left and right. And also there is no statistically significant difference between left and right foot in the incidence of tenotomy as by Fisher's Exact test (chi square value 0.027, $\mathrm{P}=0.871$ ).

The median Pirani score at start of the treatment was 6 (range 3-6) and at completion of casting treatment was 0.5 (range $0-1$ ). There is significant difference in the Pirani score at the start of the treatment and completion of casting treatment as by Wilcoxon signed rank test $(\mathrm{P}=0.0001)$. Also 
there is statistically significant difference in the Pirani score after treatment completion and follow up at 3 months on foot abduction brace $(\mathrm{P}=0.0001)$ and at 6 months $(\mathrm{P}=0.0001)$. The difference in Pirani score at 3 months of follow up and at 6 months of follow up are also statistically significant. ( $\mathrm{P}=0.025$, Wilcoxon signed rank test, after excluding the relapsed and residual deformity cases).

\begin{tabular}{|l|l|l|l|}
\hline & $\begin{array}{l}\text { Median } \\
\text { pirani } \\
\text { score }\end{array}$ & range & $\begin{array}{l}\text { P } \\
\text { (Wilcoxon } \\
\text { signed rank test }\end{array}$ \\
\hline $\begin{array}{l}\text { At the start of } \\
\text { treatment }\end{array}$ & 6 & $3-6$ & \\
\hline $\begin{array}{l}\text { At completion } \\
\text { of casting } \\
\text { treatment }\end{array}$ & 0.5 & $0-1$ & 0.0001 \\
\hline $\begin{array}{l}\text { At 3 months } \\
\text { of FAB }\end{array}$ & 0 & $0-1$ & 0.0001 \\
\hline At 6 months & 0 & $0-3$ & 0.0001 \\
\hline
\end{tabular}

The median Dimeglio score at the start of treatment was 19(range 14-19) and at completion of casting treatment was 4(range 4-5) at 3 months of foot abduction brace 1(range 0-2) and at 6 months of follow up 0(range 0-2). There also statistically significant difference in the Dimeglio score at start of treatment to completion of casting treatment ( $\mathrm{P}=0.0001$, Wilcoxon signed rank test), at 3 months of follow up $(\mathrm{P}=0.0001)$ and at 6 months of follow up $(\mathrm{P}=0.0001)$. The difference is also significant between ends of casting treatment to 3 months on FAB and at 6 months of follow up $(\mathrm{p}=0001$ each) the same is true between 3 months and 6 months score.

\begin{tabular}{|l|c|c|c|}
\hline & $\begin{array}{c}\text { Median } \\
\text { dimeglio } \\
\text { score }\end{array}$ & Range & $\begin{array}{c}\text { P Value } \\
\text { (Wilcoxon } \\
\text { signed rank test }\end{array}$ \\
\hline $\begin{array}{l}\text { At the start of } \\
\text { treatment }\end{array}$ & 19 & $14-19$ & 0.0001 \\
\hline $\begin{array}{l}\text { At } \\
\text { completion of } \\
\text { casting } \\
\text { treatment }\end{array}$ & 4 & $4-5$ & 0.0001 \\
$\begin{array}{l}\text { At 3 months } \\
\text { of FAB }\end{array}$ & 1 & $0-2$ & 0.0001 \\
\hline At 6 months & 0 & $0-2$ & \\
\hline
\end{tabular}

Table (5.4): Test result of Dimeglio score at different point of time with initial score by Wilcoxon signed rank test.
There is positive correlation between the initial Pirani score and number of cast required for correction assessed by spearman's rank correlation test (correlation coefficient $=0.493, \mathrm{P}=0.0001$ ).

A positive correlation also between initial Dimeglio score and number of cast has required for correction (spearmans rank correlation test, coefficient $0.454, \mathrm{P}=0.0001$ ).

From above it is clear that initial Pirani score is more predictive (correlated) to number of cast than initial Dimeglio score. The mean number of cast for patients not requiring tenotomy was 4.58 (SE-0.2710 with minimum number of cast 3 and maximum 8. For tenotomy patients it is 6.48 (SE0.453 ) with minimum 3 and maximum 10 cast.

The mean initial Pirani score for tenotomy group was 5.457(SD-0.782, SE-0.1631) and for nontenotomy group was 5.181(SD -1.063, SE0.1772 ). And there is no statistically significant difference between initial Pirani score of patient requiring tenotomy and those not requiring tenotomy $(\mathrm{P}=0.288)$.

The mean initial Dimeglio score for tenotomy group was 18.26(SD-1.251, SE-0.261) and for nontenotomy patients 17.83(SD-1.828, SE-0.305). Also there is no statistically significant difference in initial Dimeglio scores between patients requiring tenotomy and those requiring no tenotomy $(\mathrm{P}=0.330)$.

\begin{tabular}{|c|c|c|c|}
\hline \multicolumn{2}{|c|}{$\begin{array}{l}\text { Mean no of } \\
\text { Cast (SE, range) }\end{array}$} & $\begin{array}{l}\text { Mean intial } \\
\text { Pirani } \\
\text { Score (SD, SE) }\end{array}$ & $\begin{array}{l}\text { Mean intial } \\
\text { Dimeglio } \\
\text { Score (SD, SE) }\end{array}$ \\
\hline $\begin{array}{l}\text { Tenotom } \\
\mathrm{y} \\
\text { patients }\end{array}$ & $\begin{array}{l}4.58 \\
(0.271 \\
3-8\end{array}$ & $\begin{array}{l}5.46(0.782,0.163 \\
1)\end{array}$ & $\begin{array}{l}18.26(1.251,0.26 \\
1)\end{array}$ \\
\hline $\begin{array}{l}\text { Patients } \\
\text { with no } \\
\text { tenotom } \\
\mathrm{y}\end{array}$ & $\begin{array}{l}6.48 \\
(0.453,3 \\
-10)\end{array}$ & $\begin{array}{l}5.18(1.063,0.177 \\
)\end{array}$ & $\begin{array}{l}17.83(1.828, \\
0.305)\end{array}$ \\
\hline $\mathrm{P}$ value & & 0.288 & 0.330 \\
\hline
\end{tabular}

Table (5.5) Initial Pirani and Dimeglio score with Tenotomy- test result

The treatment was success in 36 patients, that is 52 foot $(88.1 \%)$, and not successful in According to Friedman Test the mean rank at start of treatment for Pirani score was 4 , and at 
completion of casting treatment 2.7, at 3 months on FAB 1.71, at 6 months of follow up 1.59. There was statistically significant difference in Pirani score in these periods $(\mathrm{P}=0.0001$, chi square value of Friedman test is 142.03)

\begin{tabular}{|l|c|}
\hline Time period & Rank (pirani) \\
\hline At start of treatment & 4 \\
\hline $\begin{array}{l}\text { At completion of casting } \\
\text { technique }\end{array}$ & 2.7 \\
\hline At 3 months & 1.71 \\
\hline At 6 months & 1.59 \\
\hline P.value & 0.0001 \\
\hline Chi square & 142.03 \\
\hline
\end{tabular}

Table (5.6) Friedman test results for Pirani score The mean rank at the start of treatment for Dimeglio score was 4 ,at the end of casting treatment 3,at 3months on FAB 1.79 and at 6 months 1.21. This indicates that there is statistically significant difference in Dimeglio score at these periods $(\mathrm{P}=0.0001$, chi square value of Friedman test is 152.024. From the chi square value it can be also conclude that Dimeglio score is more significant in determining the functional outcome than Pirani score.

\begin{tabular}{|l|c|}
\hline Time period & Rank (dimeglio) \\
\hline At start of treatment & 4 \\
\hline $\begin{array}{l}\text { At completion of casting } \\
\text { technique }\end{array}$ & 3 \\
\hline At 3 months & 1.79 \\
\hline At 6 months & 1.21 \\
\hline P.value & 0.0001 \\
\hline Chi square & 152.024 \\
\hline
\end{tabular}

There is also positive correlation between initial Pirani and Dimeglio score (spearman's rho test, correlation coefficient 0.825). The same correlation continued throughout the casting and towards the end of casting treatment the Pirani score plateaus sothat the correlation decreases (at the end of casting treatment correlation coefficient is 0.533 ). This correlation become less significant on further follow up in FAB and at 3 months, as Pirani score is same 0 value and Dimeglio score is serially decreasing, the correlation coefficient was only 0.192). Again at the end of 6 months there is positive correlation between Pirani and Dimeglio score because both are touches or around 0 value (correlation coefficient 0.589 , excluding the relapsed cases).This indicates that both Pirani and
Dimeglio scores can be used for assessing the progress at the time of casting treatment but Dimeglio is more useful in follow up periods as Pirani score plateau towards the end of treatment.

\begin{tabular}{|l|c|}
\hline Time period & $\begin{array}{c}\text { Spearman's correlation } \\
\text { coefficient }\end{array}$ \\
\hline At start of treatment & 0.825 \\
\hline $\begin{array}{l}\text { At the end of casting } \\
\text { treatment }\end{array}$ & 0.533 \\
\hline At 3 months on FAB & 0.192 \\
\hline At 6 months of follow up & 0.589 \\
\hline
\end{tabular}

Table (5.8) Correlation between Pirani and Dimeglio score by spearman's test

\section{Discussion}

The ponseti technique has been effective at both short and long term follow up. This technique involves two phases, the correction phase where the deformity is corrected by serial manipulation and casting, and the maintenance phase were the correction achieved is maintained in the growing foot. The use of foot abduction brace after casting treatment and tenotomy is an important part of ponseti technique and in this second phase is where chance of recurrence usually occurs and to prevent this it is advised that to use foot abduction braces once the foot deformity correction was obtained.

This study shows that initial Pirani and Dimeglio scores can be used to roughly estimate the number of weekly cast required for correction. That is higher the initial score the higher the number of cast required. Among them Pirani score is more predictive of the number of cast than Dimeglio score. With each cast the Pirani and Dimeglio scores are gradually decreasing, which means that there was increase in functional outcome of foot. But there was no correlation between initial Pirani and Dimeglio score to the need of Tenotomy in the later stage of the treatment, and this finding was against the previously demonstrated association in many studies. Also it is possible to explain the disease prognosis based on the severity of deformity at initial time, using these scoring system 
Tenotomy is the only area of Ponseti casting method that involve surgical intervention. All deformities except equinus must be corrected before this procedure.

If the deformity recurs the casting technique should be restarted as early as possible even though a number of studies support the finding that surgical methods have good results after recurrences .Ponseti method to be tried before surgery to avoid fibrosis, scar tissue and to prevent anaesthetic complications. The success rate of the Ponseti technique is good in patients with recurrence of the deformity also. If the first treatment was not Ponseti then also this technique is effective in recurrence. Nogueira et al reports that in patients who had unsuccessful surgical treatment, $86 \%$ were corrected by Ponseti method. In this study it is observed that Pirani score plateaus just prior to completion of casting treatment unlike Dimeglio score, there is still a gradual fall at the same time. So it is better to use both scores at the casting treatment time but once that time is over, the Dimeglio score is more useful for follow up, in assessing the functional outcome. From this it is concluded that both scores can be used for clubfoot evaluation at the time of casting treatment depending on surgeon's choice as they do not show any superiority over the other at that time and it is better to use Dimeglio score at follow up after casting treatment.

By analysing the socio-demographic data the positive finding in the literature that is in consistence with my study group was the more prevalence of clubfoot in male children.

Based on the current data of this study the Ponseti casting technique has excellent early results and decreases the necessity of extensive surgical procedures at early stages. And now a days, in consistence with this study findings, Ponseti technique is accepted as the gold standard for idiopathic congenital talipes equinovarus. Short term outcome from this study has shown that Ponseti technique can be applied as the primary treatment of idiopathic congenital talipes equinovarus and also anticipate that the long term results to be similar and to correspond to short term outcome as depicted here. Long term follow up needed for actual determination of recurrence/relapse and residual deformity assessment.

Also from the study it is found that Pirani and Dimeglio scoring system to be practicable, reproducible and helpful in the management of idiopathic congenital talipes equinovarus by the Ponseti method.

\section{Summary and Conclusion}

In infants with idiopathic CTEV, a proper correction, thereby the functional outcome can be obtained by using the Ponseti method and can be used as the primary treatment modality. Both Pirani and Dimeglio scores can be successfully used for the evaluation especially during casting treatment and do not show any superiority over another. They are practical, reproducible and helpful in the management of the disease. But once the patient is put in the brace, it is the Dimeglio score which is more useful. Hence both can be used effectively used in daily practice depending on surgeon's choice.

There is a definitive correlation between Pirani and Dimeglio scores in the first phase of the treatment that is the casting time. But the same decreases during follow up, when patient is on follow up or the bracing period, as Pirani score plateaus meantime. By Ponseti technique with each cast the Pirani and Dimeglio scores decreases and thereby the functional outcome of the foot improves.

There was no correlation between initial Pirani and Dimeglio scores to Tenotomy. The Ponseti method should be the first choice in the treatment of both primary cases and relapse/recurrences. The literature until now also points that the Ponseti method as the gold standard in clubfoot treatment and so the new methodologies should be compared with Ponseti method to evaluate their benefit. 
The results or functional outcome of the clubfoot treatment by Ponseti method in this study is good and this method is very safe, efficient treatment for the correction of clubfoot and decreases need for extensive corrective surgical procedures

\section{Bibliography}

1. Wynne-Davies R. Family Studies And The Cause of Congenital Club Foot. Talipes Equinovarus, Talipes Calcaneo-Valgus And Metatarsus Varus. J Bone Joint Surg Br. 1964 Aug;46:445-63.

2. A Dimeglio FB. Dimeglio A, Bonnet F, Mazeau P, DeRosa V. Orthopaedic treatment and passive motion machine: consequences for the surgical treatment of clubfoot. J Pediatr Orthop B. 1996;5(3): 173-80.

3. Laaveg SJ, Ponseti IV. Long-term results of treatment of congenital club foot. $\mathrm{J}$ Bone Joint Surg Am. 1980 Jan;62(1):2331.

4. Dimeglio A, Bensahel $\mathrm{H}$, Souchet $\mathrm{P}$, Mazeau P, Bonnet F. Classification of clubfoot. Pediatr Orthop Part B. 1995;4(2):129-36.

5. Flynn JM, Donohoe M, Mackenzie WG. An independent assessment of two clubfoot-classification systems. J Pediatr Orthop. 1998 Jun;18(3):323-7.

6. Wynne-Davies R. Family Studies and the Cause of Congenital Club Foot. J Bone Joint Surg Br. 1964 Aug 1;46-B(3):44563.

7. Bakalis S, Sairam S, Homfray $T$, Harrington K, Nicolaides K, Thilaganathan B. Outcome of antenatally diagnosed talipes equinovarus in an unselected obstetric population. Ultrasound Obstet Gynecol. 2002 Sep 1;20(3):226-9.

8. Gurnett CA, Boehm S, Connolly A, Reimschisel T, Dobbs MB. Impact of congenital talipes equinovarus etiology on treatment outcomes. Dev Med Child Neurol. 2008 Jul;50(7):498-502.
9. Gordon N. Arthrogryposis multiplex congenita. Brain Dev. 1998 Oct;20(7):50711.

10. Hootnick DR, Levinsohn EM, Crider RJ, Packard DS. Congenital arterial malformations associated with clubfoot. A report of two cases. Clin Orthop. 1982 Jul;(167):160-3.

11. Dunn PM. Congenital postural deformities: perinatal associations. Proc R Soc Med. 1972 Aug;65(8):735-8.

12. Bonnell J, Cruess RL. Anomalous Insertion of the Soleus Muscle as a Cause of Fixed Equinus Deformity. J Bone Jt Surg Am. 1969 Jul 1;51(5):999-1000.

13. Gurnett CA, Alaee F, Kruse LM, Desruisseau DM, Hecht JT, Wise CA, et al. Asymmetric Lower-Limb Malformations in Individuals with Homeobox PITX1 Gene Mutation. Am J Hum Genet. 2008 Nov 17;83(5):61622.

14. Lochmiller C, Johnston D, Scott A, Risman M, Hecht JT. Genetic epidemiology study of idiopathic talipes equinovarus. Am J Med Genet. 1998 Sep 1;79(2):90-6.

15. Beals RK. Club foot in the Maori: a genetic study of 50 kindreds. N Z Med J. 1978 Aug 23;88(618):144-6.

16. Chung CS, Nemechek RW, Larsen LI, Ching GH. Genetic and epidemiological studies of clubfoot in Hawaii. General and medical considerations. Hum Hered. 1969;19(4):321-42.

17. Wynne-Davies R. Genetic and environmental factors in the etiology of talipes equinovarus. Clin Orthop. 1972 May;84:9-13.

18. Rebbeck TR, Dietz FR, Murray JC, Buetow KH. A single-gene explanation for the probability of having idiopathic talipes equinovarus. Am J Hum Genet. 1993 Nov;53(5):1051-63. 
19. Wang JH, Palmer RM, Chung CS. The role of major gene in clubfoot. Am J Hum Genet. 1988 May;42(5):772-6.

20. de Andrade M, Barnholtz JS, Amos CI, Lochmiller C, Scott A, Risman M, et al. Segregation analysis of idiopathic talipes equinovarus in a Texan population. Am $\mathbf{J}$ Med Genet. 1998 Sep 1;79(2):97-102.

21. Chapman C, Stott NS, Port RV, Nicol RO. Genetics of club foot in Maori and Pacific people. J Med Genet. 2000 Sep 1;37(9):680-3.

22. Kruse LM, Dobbs MB, Gurnett CA. Polygenic threshold model with sex dimorphism in clubfoot inheritance: the Carter effect. J Bone Joint Surg Am. 2008 Dec;90(12):2688-94.

23. Philip J, Silver RK, Wilson RD, Thom EA, Zachary JM, Mohide P, et al. Late firsttrimester invasive prenatal diagnosis: results of an international randomized trial. Obstet Gynecol. 2004 Jun;103(6):1164-73.

24. Tredwell SJ, Wilson D, Wilmink MA, Canadian Early and Mid-Trimester Amniocentesis Trial Group (CEMAT), and the Canadian Pediatric Orthopedic Review Group. Review of the effect of early amniocentesis on foot deformity in the neonate. J Pediatr Orthop. 2001 Oct;21(5): 636-41.

25. Honein MA, Paulozzi LJ, Moore CA. Family history, maternal smoking, and clubfoot: an indication of a geneenvironment interaction. Am J Epidemiol. 2000 Oct 1;152(7):658-65.

26. Hecht JT, Ester A, Scott A, Wise CA, lovannisci DM, Lammer EJ, et al. NAT2 variation and idiopathic talipes equinovarus (clubfoot). Am J Med Genet A. 2007 Oct 1;143A(19):2285-91.

27. Karakurt L, Yilmaz E, Serin E, Bekta§ B, Cikim G, Giirsu F. Plasma total homocysteine level in mothers of children with clubfoot. J Pediatr Orthop. 2003 Oct;23(5):658-60.
28. Sharp L, Miedzybrodzka Z, Cardy AH, Inglis J, Madrigal L, Barker S, et al. The C677T polymorphism in the methylenetetrahydrofolate reductase gene (MTHFR), maternal use of folic acid supplements, and risk of isolated clubfoot: A case-parent-triad analysis. Am J Epidemiol. 2006 Nov 1;164(9):852-61.

29. Wang L-L, Fu W-N, Li-Ling J, Li Z-G, Li L-Y, Sun K-L. HOXD13 may play a role in idiopathic congenital clubfoot by regulating the expression of FHL1. Cytogenet Genome Res. 2008;121(34):189-95.

30. Heck AL, Bray MS, Scott A, Blanton SH, Hecht JT. Variation in CASPIO gene is associated with idiopathic talipes equinovarus. J Pediatr Orthop. 2005 Oct;25 (5):598-602.

31. Shapiro MD, Marks ME, Peichel CL, Blackman BK, Nereng KS, Jonsson B, et al. Genetic and developmental basis of evolutionary pelvic reduction in threespine sticklebacks. Nature. 2004 Apr 15;428(6984):717-23.

32. Sung SS, Brassington A-ME, Grannatt K, Rutherford A, Whitby FG, Krakowiak PA, et al. Mutations in genes encoding fasttwitch contractile proteins cause distal arthrogryposis syndromes. Am J Hum Genet. 2003 Mar;72(3):681-90.

33. Sung SS, Brassington A-ME, Krakowiak PA, Carey JC, Jorde LB, Bamshad M. Mutations in TNNT3 Cause Multiple Congenital Contractures: A Second Locus for Distal Arthrogryposis Type 2B. Am J Hum Genet. 2003 Jul;73(1):212-4.

34. Toydemir RM, Rutherford A, Whitby FG, Jorde LB, Carey JC, Bamshad MJ. Mutations in embryonic myosin heavy chain (MYH3) cause Freeman-Sheldon syndrome and Sheldon-Hall syndrome. Nat Genet. 2006 May;38(5):561-5.

35. Veugelers M, Bressan M, McDermott DA, Weremowicz S, Morton CC, Mabry CC, et 
al. Mutation of perinatal myosin heavy chain associated with a Carney complex variant. N Engl J Med. 2004 Jul 29;351(5):460-9.

36. Gurnett CA, Alaee F, Desruisseau D, Boehm S, Dobbs MB. Skeletal muscle contractile gene (TNNT3, MYH3, TPM2) mutations not found in vertical talus or clubfoot. Clin Orthop. 2009 May;467(5):1195-200.

37. Boehm S, Limpaphayom N, Alaee F, Sinclair MF, Dobbs MB. Early results of the Ponseti method for the treatment of clubfoot in distal arthrogryposis. J Bone Joint Surg Am. 2008 Jul;90(7):1501-7.

38. Turco VJ. Surgical Correction of the Resistant Club Foot. J Bone Jt Surg Am. 1971 Apr 1;53(3):477-97.

39. Turco VJ. Resistant congenital club foot-one-stage posteromedial release with internal fixation. A follow-up report of a fifteen-year experience. J Bone Jt Surg Am. 1979 Sep 1;61(6):805-14.

40. Hudson I, Catterall A. Posterolateral release for resistant club foot. J Bone Joint Surg Br. 1994 Mar;76(2):281-4.

41. McKay DW. New concept of and approach to clubfoot treatment: section Iprinciples and morbid anatomy. J Pediatr Orthop. 1982 Oct;2(4):347-56.

42. Simons GW. Complete subtalar release in club feet. Part II--Comparison with less extensive procedures. J Bone Joint Surg Am. 1985 Sep;67(7):1056-65.

43. Atar D, Lehman WB, Grant AD. Complications in clubfoot surgery. Orthop Rev. 1991 Mar;20(3):233-9.

44. Weseley MS, Barenfeld PA, Barrett N. Complications of the treatment of clubfoot. Clin Orthop. 1972 May;84:93-6.

45. Aronson J, Puskarich CL. Deformity and disability from treated clubfoot. J Pediatr Orthop. 1990 Feb;10(I):109-19.

46. Dobbs MB, Nunley R, Schoenecker PL. Long-term follow-up of patients with clubfeet treated with extensive soft-tissue release. J Bone Joint Surg Am. 2006 May;88(5):986-96.

47. Hutchins PM, Foster BK, Paterson DC, Cole EA. Long-term results of early surgical release in club feet. J Bone Joint Surg Br. 1985 Nov;67(5):791-9.

48. Ippolito E, Farsetti P, Caterini R, Tudisco C. Long-term comparative results in patients with congenital clubfoot treated with two different protocols. J Bone Joint Surg Am. 2003 Jul;85- A(7):1286-94.

49. Ponseti IV. Treatment of congenital club foot. J Bone Jt Surg Am. 1992 Mar 1;74(3):448-54.

50. Cooper DM, Dietz FR. Treatment of idiopathic clubfoot. A thirty-year followup note. J Bone Joint Surg Am. 1995 Oct;77(10):1477-89.

51. Dobbs MB, Morcuende JA, Gurnett CA, Ponseti IV. Treatment of idiopathic clubfoot: an historical review. Iowa Orthop J. 2000;20:59-64.

52. Kite JH. Some Suggestions on the Treatment of Club Foot by Casts. J Bone It Surg Am. 1963 Mar 1;45(2):406-12.

53. The classic. Principles involved in the treatment of congenital clubfoot by $\mathrm{J}$. Hiram Kite, M.D. reprinted from J. Bone Joint Surg. 21:595-606, 1939. Clin Orthop. 1972 May;84:4-8.

54. Lovell WW, Farley D. Treatment of congenital clubfoot. ONA J. 1979 Nov;6(11):453-6.

55. Stewart SF. Club-Foot: Its Incidence, Cause, and Treatment. J Bone .1t Surg Am. 1951 Jul I ;33(3):577-90.

56. Coss HS, Hennrikus WL. Parent satisfaction comparing two bandage materials used during serial casting in infants. Foot Ankle Int. 1996 Aug;17(8):483-6.

57. Pittner DE, Klingele KE, Beebe AC. Treatment of clubfoot with the Ponseti 
method: a comparison of casting materials. J Pediatr Orthop. 2008 Mar;28(2):250-3.

58. Morcuende JA, Abbasi D, Dolan LA, Ponseti IV. Results of an accelerated Ponseti protocol for clubfoot. J Pediatr Orthop. 2005 Oct;25(5):623-6.

59. Dobbs MB, Rudzki JR, Purcell DB, Walton T, Porter KR, Gurnett CA. Factors predictive of outcome after use of the Ponseti method for the treatment of idiopathic clubfeet. J Bone Joint Surg Am. 2004 Jan;86-A(1):22-7.

60. Lourenco AF, Morcuende JA. Correction of neglected idiopathic club foot by the Ponseti method. J Bone Joint Surg Br. 2007 Mar;89(3):378-81.

61. Tindall AJ, Steinlechner CWB, Lavy CBD, Mannion S, Mkandawire N. Results of manipulation of idiopathic clubfoot deformity in Malawi by orthopaedic clinical officers using the Ponseti method: a realistic alternative for the developing world? J Pediatr Orthop. 2005 Oct;25(5):627-9.

62. Chen RC, Gordon JE, Luhmann SJ, Schoenecker PL, Dobbs MB. A new dynamic foot abduction orthosis for clubfoot treatment. J Pediatr Orthop. 2007 Aug;27(5):522-8.

63. Ponseti IV, Zhivkov M, Davis N, Sinclair M, Dobbs MB, Morcuende JA. Treatment of the complex idiopathic clubfoot. Clin Orthop. 2006 Oct;451:171-6.

64. Garg S, Dobbs MB. Use of the Ponseti method for recurrent clubfoot following posteromedial release. Indian $\mathrm{J}$ Orthop. 2008 Jan;42(1):68-72.

65. Dobbs MB, Gordon JE, Walton T, Schoenecker PL. Bleeding complications following percutaneous tendoachilles tenotomy in the treatment of clubfoot deformity. J Pediatr Orthop. 2004 Aug;24(4):353-7.

66. Barker SL, Lavy CBD. Correlation of clinical and ultrasonographic findings after
Achilles tenotomy in idiopathic club foot. J Bone Joint Surg Br. 2006 Mar;88(3):3779.

67. Changulani M, Garg NK, Rajagopal TS, Bass A, Nayagam SN, Sampath J, et al. Treatment of idiopathic club foot using the Ponseti method. Initial experience. J Bone Joint Surg Br. 2006 Oct;88(10):1385-7.

68. Morcuende JA, Dolan LA, Dietz FR, Ponseti IV. Radical reduction in the rate of extensive corrective surgery for clubfoot using the Ponseti method. Pediatrics. 2004 Feb;113(2):376-80.

69. Bensahel H, Catterall A, Dimeglio A. Practical applications in idiopathic clubfoot: a retrospective multicentric study in EPOS. J Pediatr Orthop. 1990 Apr;10(2):186-8.

70. Dimeglio A, Bonnet F, Mazeau P, De Rosa V. Orthopaedic treatment and passive motion machine: consequences for the surgical treatment of clubfoot. J Pediatr Orthop Part B. 1996;5(3):173-80.

71. Richards BS, Faulks S, Rathjen KE, Karol LA, Johnston CE. Jones SA. A comparison of two nonoperative methods of idiopathic clubfoot correction: the Ponseti method and the French functional (physiotherapy) method. J Bone Joint Surg Am. 2008 Nov;90(11):2313-21.

72. Van Campenhout A, Molenaers G, Moens P, Fabry G. Does functional treatment of idiopathic clubfoot reduce the indication for surgery? Call for a widely accepted rating system. J Pediatr Orthop Part B. 2001 Oct;10(4):315-8.

73. Bensahel H, Csukonyi Z, Desgrippes Y, Chaumien JP. Surgery in residual clubfoot: one-stage medioposterior release "a la carte." J Pediatr Orthop. 1987 Apr;7(2):145-8.

74. Abdelgawad AA, Lehman WB, van Bosse HJP, Scher DM, Sala DA. Treatment of idiopathic clubfoot using the Ponseti method: minimum 2-year follow-up. J 
Pediatr Orthop Part B. 2007 Mar;16(2):98105.

75. Dietz F, Cole W, Tosi L, Carroll N, Wemer R, Comstock D, et al. A search for the gene(s) predisposing to idiopathic clubfoot. Clin Genet. 2005 Apr;67(4):3612.

76. Porecha MM, Parmar DS, Chavda HR. Mid-term results of Ponseti method for the treatment of congenital idiopathic clubfoot--(a study of 67 clubfeet with mean five year follow-up). J Orthop Surg. 2011;6:3.

77. Garceau GJ, Manning KR. Transposition of the Anterior Tibial Tendon in the Treatment of Recurrent Congenital ClubFoot. J Bone Jt Surg Am. 1947 Oct 1;29(4):1044-8.

78. Fried A. Recurrent congenital clubfoot; the role of the M. tibialis posterior in etiology and treatment. J Bone Joint Surg Am. 1959 Mar;41-A(2):243-52.

79. Wainwright AM, Auld T, Benson MK, Theologis TN. The classification of congenital talipes equinovarus. J Bone Joint Surg Br. 2002 Sep;84(7):1020-4.

80. Tibrewal SB, Benson MK, Howard C, Fuller DJ. The Oxford club-foot programme. J Bone Joint Surg Br. 1992 Jul 1;74-B(4):528-33.

81. Scher DM, Feldman DS, van Bosse HJP, Sala DA, Lehman WB. Predicting the need for tenotomy in the Ponseti method for correction of clubfeet. J Pediatr Orthop. 2004 Aug;24(4):349-52.

82. Cooper DM, Dietz FR. Treatment of idiopathic clubfoot. A thirty-year followup note. J Bone Joint Surg Am. 1995 Oct;77(10):1477-89.

83. Herzenberg JE, Radler C, Bor N. Ponseti versus traditional methods of casting for idiopathic clubfoot. J Pediatr Orthop. 2002 Aug;22(4):517-21.

84. Lehman WB, Mohaideen A, Madan S, Scher DM, Van Bosse HJP, lannacone M, et al. A method for the early evaluation of the Ponseti (Iowa) technique for the treatment of idiopathic clubfoot. J Pediatr Orthop Part B. 2003 Mar;12(2):133-40.

85. Ponseti IV, Smoley EN. The Classic: Congenital Club Foot: The Results of Treatment. Clin Orthop. 2009 May;467(5): 1 133-45.

86. Thacker MM, Scher DM, Sala DA, van Bosse HJP, Feldman DS, Lehman WB. Use of the foot abduction orthosis following Ponseti casts: is it essential? J Pediatr Orthop. 2005 Apr;25(2):225-8.

87. Mootha AK, Saini R, Krishnan V, Bali K, Kumar V, Dhillon MS. Management of idiopathic clubfoot by the Ponseti technique: our experience at a tertiary referral centre. J Orthop Sci Off J Jpn Orthop Assoc. 2011 Mar;16(2):184-9.

88. Short term outcome of congenital clubfoot treated by Ponseti method [Internet]. Pakistan Journal of Medical Sciences. 2012 [cited 2015 Dec 6]. Available from: http://pjms.com.pk/index.php/pjms/article/ view/ 1732

89. Chomiak J, Frydrychova M, Ostadal M, Matejicek M. [The Ponseti method of treatment of congenital clubfoot-first experiences]. Acta Chir Orthop Traumatol

90. Colburn M, Williams M. Evaluation of the treatment of idiopathic clubfoot by using the Ponseti method. J Foot Ankle Surg Off Publ Am Coll Foot Ankle Surg. 2003 Oct;42(5):259-67.

91. Iltar S, Uysal M, Alemdaroglu KB, Aydogan NH, Kara T, Atlihan D. Treatment of clubfoot with the Ponseti method: should we begin casting in the newborn period or later? J Foot Ankle Surg Off Publ Am Coll Foot Ankle Surg. 2010 Oct;49(5):426-31.

92. Yagmurlu MF, Ermis MN, Akdeniz HE, Kesin E, Karakas ES. Ponseti management of clubfoot after walking age. Pediatr Int 
Off J Jpn Pediatr Soc. 2011 Feb;53(1):859.

93. Dogan A, Korkmaz M, Cengiz N, Kalender AM, Gokalp MA. Biomechanical comparison of Achilles tenotomy and achilloplasty techniques in young rats: an experimental study. J Am Podiatr Med Assoc. 2009 Jun;99(3):216-22.

94. 65. Dobbs MB, Gordon JE, Walton T, Schoenecker PL. Bleeding complications following percutaneous tendoachilles tenotomy in the treatment of clubfoot deformity. J Pediatr Orthop. 2004 Aug;24(4):353-7.

95. El-Mowafi H, El-Alfy B, Refai M. Functional outcome of salvage of residual and recurrent deformities of clubfoot with Ilizarov technique. Foot Ankle Surg Off J Eur Soc Foot Ankle Surg. 2009;15(1):3-6.

96. Ferreira RC, Costa MT. Recurrent clubfoot--approach and treatment with external fixation. Foot Ankle Clin. 2009 Sep;14(3):435-45.

97. Park S-S, Kim SW, Jung B-S, Lee HS, Kim JS. Selective soft-tissue release for recurrent or residual deformity after conservative treatment of idiopathic clubfoot. J Bone Joint Surg Br. 2009 Nov;91(11):1526-30.

98. Nogueira MP, Ey Bathe AM, Alves CG. Is it Possible to Treat Recurrent Clubfoot with the Ponseti Technique After Posteromedial Release?: A Preliminary Study. Clin Orthop. 2009 May;467(5): 1298-305.

99. Lehman WB. The clubfoot. New York: J.B.Lippincott; 1980 99. Ponseti IV. Congenital Clubfoot: Fundamentals of Treatment. New York: Oxford University Press, 1996.

100. Pirani S. A reliable and valid method of assessing the amount of deformity in the congenital clubfoot. St Louis, MO: Pediatric Orthopaedic Society of North America; 2004.
101.

Elmslie RC. The principles of treatment of congenital talipes equinovarus. J. Orthop Surg. 1920;2:669.

102. Phelps AM. The present status of the open incision method for talipes equinovarus. New Engl. Med. Mon. 1891;10:217.

103. Jones R. Discussion on the treatment of intractable talipes equinovarus. Trans Brit Orthop Soc. 1895;1:20.

104. Percas-Ponseti H. Homage to Iowa: The inside story of Ignacio V. Ponseti. Iowa City, IA: The University of Iowa Press; 2007.

105. Sayre L. A Practical Manual of the Treatment of Clubfoot. New York, NY: D. Appleton and Company; 1869.

106. Bradford EH. Treatment of clubfoot. J Bone Joint Surg Am. 1889;s1-1:89115.

107. Taylor HL. The treatment of clubfoot by continuous leverage. J Bone Joint Surg Am. 1893;s1-5:178-182.

108. Milliken FH. Treatment of infantile club-foot preliminary to operation. J Bone Joint Surg Am. 1890;s1-3:50-62.

109. Willard DF. Comparison of operative methods in the treatment of clubfoot. J Bone Joint Surg Am. 1893;s15:225-231.

110. Ponseti IV, Smoley EN. Congenital club foot: The results of treatment. J Bone Joint Surg Am. 1963;45:261-275.

111. Ponseti IV, Campos J. Observations on pathogenesis and treatment of congenital clubfoot. Clin Orthop Relat Res. 1972;84:50-60.

112. Ponseti IV, Friedman B. Prognosis in idiopathic scoliosis. J Bone Joint Surg Am. 1950;32:381-395.

113. Ponseti IV. To Parents of Children Born with Clubfeet. Available at: http://www.uihealthcare.com/topics/medic 
aldepartments/ orthopaedics/clubfeet/.

Accessed January 7, 2009.

114. Bechtol, C. 0 and Mossman, H. W.: Club-foot. An embryological study of associated muscle abnormalities, J. Bone Joint Surg. 32A:827, 1950.

115. Talipes equinovarus. A review of eighty-four cases after completion of treatment, J. Bone Joint Surg. 46B:464, 1964.

116. Browne, D.: Talipes equonovarus, Lancet ii:969, 1934.

117. Brockman, E. P.: Congenital Clubfoot (Talipes Equinovarus), New York, William Wood and Co., 1930; pp. 1-59.

118. Dittrich, R. J.: Pathogenesis of congenital club-foot, J. Bone Joint Surg. 12:373, 1930.

119. Durante, G. and Courtillier, L.: Atrophic musculaire par regression embryonnaire totale chez un enfant atteint de pied bot paralytique congenital. Bull. Soc. Obst. Paris 2:366, 1899.

120. Hoffa, Albert: Lehrbuch der orthopaedischen Chirurgie, 5th ed. Stuttgart, Ferdinand Enke, 1905; p. 734.

121. Bolim, Max: Das menschliche Bein. Deutsche Orthopaedie, Band

122. 124. Hirsch, C.: Observations on early operative treatment of congenital club-foot, Bull. Hosp. Joint Dis. 31:173, 1960.

123. Adams, W.: Club-foot: Its Causes, Pathology, and Treatment. London, J. and A. Churchill, 1866.

124. Irani, R. N. and Sherman, Mary S.: The pathological anatomy of clubfoot, J. Bone Joint Surg. 45A, No. 1, 1963.

125. Harris, H. A,: Posture in industry, Lancet ii:56, 1942.
126.

Kite, J. H.: The treatment of congenital club-feet, Surg. Gynecol. Obstet. 61:190, 1935.

127. Huson, A.: Een OntleedkundinFunctioneel Onderzoek van de Voetwortel. Leiden, Proefschrift, 1961.

128. Hicks, J. H.: The mechanics of the foot. J. Anat. Part I, 87:345; Part II, 88:25, 1953-54.

129. Ponseti, I. V. and Smoley, E. N.: Congenital club foot: The results of treatment, J. Bone Joint Surg. 45A:261, 1963.

130. Principles involved in the treatment of congenital club foot, J. Bone Joint Surg. 21:595, 1939.

131. Garceau, G. J. and Manning, K. R.: Transposition of the anterior tibial tendon in the treatment of recurrent congenital club-foot, J. Bone Joint Surg. 29:1044, 1947.

132. Spiegel DA, Shrestha OP, Sitoula P, Rajbhandary T, Bijukachhe B, Banskota AK. Ponseti method for untreated idiopathic clubfeet in Nepalese patients from 1 to 6 years of age. Clin Orthop Relat Res. 2008 Nov 6 [Epub ahead of print].

133. John Anthony Herring. Tachd Jian's pediatric orthopaedic. 4th ed. Saunders 2007: 1076-1086. 136. Pirani S, Outerbridge HK, Sawatzky B, Stothers K. A reliable method of clinically evaluating a virgin clubfoot evaluation.21stSICOT Congress 1999. 